\title{
The effect of fish protein hydrolysate (FPH) substitution complementary feeding formula on the albumin levels of Sprague Dawley rat
}

\author{
${ }^{1}$ Asmak, N., ${ }^{2}$ Kusmiyati-Tjahjono, D.K., ${ }^{3}$ Chasanah, E., ${ }^{3}$ Fawzya, Y.N., ${ }^{3}$ Martosuyono, P., \\ ${ }^{1}$ Nuryanto and ${ }^{1 *}$ Afifah, D.N. \\ ${ }^{1}$ Department of Nutrition Science, Faculty of Medicine, Diponegoro University, Semarang \\ ${ }^{2}$ Departement of Biomedical Science, Faculty of Medicine, Diponegoro University, Semarang \\ ${ }^{3}$ Research and Development Center for Marine and Fisheries Product Processing and Biotechnology,
}

Jakarta

\section{Article history: \\ Received: 29 December 2019 \\ Received in revised form: 14 \\ February 2020 \\ Accepted: 16 March 2020 \\ Available Online: 30 May \\ 2020}

\section{Keywords:}

Sprague Dawley rats,

Albumin levels,

Complementary feeding,

Fish protein hydrolyzate

(FPH)

DOI:

https://doi.org/10.26656/fr.2017.4(S3).S07

\begin{abstract}
Complementary feeding is given from the age of six months to meet nutritional needs. Complementary feeding with the composition of skim milk and green bean flour enriched with fish protein hydrolyzate (FPH) from kuniran fish (Upeneus moluccensis) was chosen as a source of protein to increase the nutritional intake of complementary feeding. The purpose of this study was to study the effect on Sprague Dawley rat albumin levels after the administration of complementary feeding formula with fish protein hydrolyzate substitution (FPH). This research was a True Experimental Design research with completely randomized design (CRD). A total of twenty-five Sprague Dawley male rats were acclimatized for 4 days, then divided into five regulatory groups. The control group was given standard feeding, T1 group was given F1 treatment (18\% skim milk, 7.6\% FPH flour, and $37.8 \%$ mung bean flour), T2 group was given F2 treatment (15\% skim milk, 7.6\% FPH flour, and $45.6 \%$ mung bean flour), T3 group was given F3 (18\% skim milk, $6.2 \%$ FPH flour, and $45.6 \%$ mung bean flour), and group T4 given commercial treatment $\left(\right.$ Promina $\left.{ }^{\circledR}\right)$. Giving complementary feeding through sonde for 14 days at a dose of $0.18 \mathrm{~g} / 50 \mathrm{gBW}$ per day. Albumin levels were measured before and after the administration of complementary feeding treatment. Research data were analyzed using Mann Whitney on SPSS. Research shows that there were significant differences in the rate of albumin levels ( $p>0.05$ ). Complementary feeding formula with the highest albumin levels in $\mathrm{T} 2$ $(4.89 \mathrm{~g} / \mathrm{dL})$.
\end{abstract}

\section{Introduction}

Malnutrition in children under five (under five years) is still a big problem in developing countries, especially Indonesia. The results of Riset Kesehatan Dasar (RISKESDAS) report that the nutritional status of children under five in Indonesia is still quite high, namely: the prevalence of underweight $17.7 \%$, consisting of $3.9 \%$ malnutrition and $13.8 \%$ undernutrition; stunting prevalence of $30.8 \%$ consists of $11.5 \%$ very short and $19.3 \%$ short; wasting prevalence is $10.2 \%$ consisting of $3.5 \%$ very thin and $6.7 \%$ thin (RISKESDAS, 2018). The RISKESDAS data (2018) can be concluded that there are still many children under five in Indonesia who are malnourished and need special treatment so that there is no increase in the number of undernourished children under five.

Complementary feeding is food that is given to babies at the age of 6 months and above. This is because breastfeeding alone is not enough to meet the nutritional needs of infants. Giving complementary feeding serves to accustom the baby to a variety of nutritious foods, easily digested, preferred (organoleptically accepted), practical in serving, and as an introduction to infants of family food. The comparison of the ingredients of the complementary feeding compilers must be arranged so that they can produce complementary feeding that meet the nutritional needs of infants (Setyani et al., 2013).

The toddler period is a period where growth and development occur very quickly so that adequate nutrition is needed to support growth and development so that the absolute nutritional needs are met so that the baby's growth is not stopped or slowed down. Prevention of malnutrition problems in infants can be done with several things, one of which is the development of food 
products. Instant powder product that utilizes green beans and skim milk enriched with fish protein hydrolyzate (FPH) is a food product that is developed with the aim of additional food for toddlers with poor nutritional status.

Hydrolyzed protein is a protein that increases hydrolytic degradation with acids, bases, or proteolytic enzymes. Contains amino acids and peptides. Protein hydrolyzate is a food ingredient that is easily digested by the body. The process of making protein hydrolyzate in the industry uses an enzymatic process, which is more suitable and cheaper. The processing process is faster and provides protein hydrolyzate without the addition of essential amino acids. The use of protease enzymes in protein hydrolyzate processes is carried out to obtain quality products (Chalamaiah et al., 2012). The local microbial protease enzyme from the bacterium Bacillus licheniformis can be used in the manufacture of FPH. Kuniran fish (Upeneus moluccensis) was chosen in the manufacture of FPH because it is one of the fish that live and eat on the seabed (demersal) and is easily obtained at sea (Asriyana and Irawati, 2018).

Green bean protein contains 20-25\%, green bean protein rich in amino acids leucine, arginine, isoleucine, valine, and lysine. While the protein is questioned by amino acids such as methionine and cysteine. Mung beans are very beneficial for the body and health (Martianingsih et al., 2016). Skim milk is a part of milk that is lost after it has been taken partially or completely. Skim milk contains all the milk nutrients, less fat and fatsoluble vitamins. Skim milk is given as non-fat milk powder which contains a lot of protein and water content of 5\% (Susanti and Hidayat, 2016). The albumin level was chosen as an indicator in determining the baseline of what albumin is the most abundant plasma protein in human blood (60\%). Album levels also contribute to changes in nutritional status and malnutrition (Gibson, 2005; Banh, 2006; Kuyuza et al., 2007; Smith et al., 2007; Kirilova et al., 2011).

Instant powder products using the composition of FPH flour, mung bean flour, and skim milk as a source of protein combined with brown rice flour, refined sugar, and vegetable oil can be a breakthrough to produce complementary feeding. The right instant powder formulation has the opportunity to be developed on a commercial scale as a nutritional baby food supplement that is suitable for the baby's needs. The purpose of this study was to determine the effect of Sprague Dawley rat albumin levels after giving complementary feeding formula with FPH substitution.

\section{Materials and methods}

\subsection{Research design and experimental animals}

This research was a True Experimental Design research with a Completely Randomized Design (CRD) conducted in a laboratory in vivo. This study was approved by the Health Research Ethics Commission (HREC) of the Faculty of Medicine, Diponegoro University. The research was conducted at the Laboratory of the Center for Food and Nutrition Studies at Gajah Mada University, Yogyakarta.

The experimental animals used were Sprague Dawley male rats aged 21-23 days with a bodyweight of 45-55 $\mathrm{g}$ in healthy condition as many as 25 mice obtained from the Laboratory of Food and Nutrition Study Center at Gajah Mada University, Yogyakarta. The inclusion criteria of this study sample were Sprague Dawley male rats, age 21-23 days, rat weight 45-55 g, and healthy. Exclusion criteria were dead rats in the study, sick mice, and mice undergoing behavioral changes (do not want to eat and are weak).

As many as twenty-five experimental animals were acclimatized for four days. During the acclimatization process until the treatment was completed the rats were given standard feed (AIN-93 G) 5 g/day and drank ad libitum, then divided into five treatment groups. Each rat was put into individual mouse cages. The difference in complementary formula feeding can be seen in Table 1. The control group was given standard feed treatment, T1 group was given F1 treatment (18\% skim milk, $7.6 \%$ FPH flour, and 37.8\% mung bean flour), T2 group was given F2 treatment (15\% skim milk, 7.6\% FPH flour, and $45.6 \%$ mung bean flour), T3 group was given F3 treatment (18\% skim milk, 6.2\% FPH flour, and 45.6\% mung bean flour), and group T4 given commercial treatment (Promina ${ }^{\circledR}$ ) Giving complementary feeding through oral sonde for 14 days at a dose of $0.18 \mathrm{~g} / 50 \mathrm{~g}$ BW/day (Muliani and Hirawati, 2011; Mardiati et al., 2016; Putri et al., 2019).

\subsection{Complementary feeding formula preparation}

The process of making complementary feeding formula was done by dry mixing and drying with a drum dryer. Dry mixing method means that all raw materials are mixed when all the ingredients are ready to be served. Brown rice flour and green beans are cooked with water into a mixture of porridge and then dried using a drum dryer $\left(1 \mathrm{rpm}\right.$ at $\left.70^{\circ} \mathrm{C}\right)$. After drying, it was sieved with 60-mesh sieve. Green bean flour and brown rice are ready to serve, then all raw materials (mung bean flour, brown rice flour, skim milk flour, FPH flour, and refined sugar) are mixed except for palm oil. Palm oil was mixed when complementary feeding porridge was 
Table 1. Standard feed composition and complementary feeding formula

\begin{tabular}{lllll}
\hline Standard Feed & \multicolumn{1}{c}{ F1 } & \multicolumn{1}{c}{ F2 } & F3 & Commercial (Promina $^{\circledR}$ ) \\
\hline Cornstarch 39.7486\% & Brown rice flour 21.6\% & Brown rice flour 16.8\% & Brown rice flour 15.2\% & Total fat 10\% \\
Casein 20\% & Green bean flour 37.8\% & Green bean flour 45.6\% & Green bean flour 45.6\% & Protein 15\% \\
$\begin{array}{l}\text { Dextrinized Cornstarch } \\
13.20 \%\end{array}$ & Skim milk 18\% & Skim milk 15\% & Skim milk 18\% & Total carbohydrates 70\% \\
Sucrose 10\% & FPH flour 7.6\% & FPH flour 7.6\% & FPH flour 6.2\% & Sodium 5\% \\
Soybean Oil 7\% & Refined sugar 5\% & Refined sugar 5\% & Refined sugar 5\% & Palm oil 10\% \\
$\begin{array}{l}\text { Alphacel Non-nutritive } \\
\text { bulk 5\% }\end{array}$ & Palm oil 10\% & Palm oil 10\% & & \\
Mineral mix (AIN-93M- & & & & Protein : 16.15\% \\
MX) 3.5\% & & & & \\
Vitamin mix (AIN-93- & Protein : 15.6\% & Protein : 15.825\% & & \\
VX) 1.0\% & & & & \\
L-Gystine 0.3\% & & & & \\
Choline Bitartrate 0.25\% & & & &
\end{tabular}

instant it wants to be served (Putri et al., 2019).

\subsection{Suspension preparation}

The suspension was a liquid preparation containing solid particles that do not dissolve in liquid form because the sample in this study was the Sprague Dawley rat, then complementary feeding was given in the form of suspension to facilitate its administration to mice. The suspension was administered orally using a sonde given to the treatment groups of T1, T2, T3, and commercial mice of $0.18 \mathrm{~g} / 50 \mathrm{~g} \mathrm{BW} /$ day in $1 \mathrm{~mL}$ of complementary feeding suspension. For the $\mathrm{C}$ treatment group, no complementary feeding suspension was given because as a positive control.

\subsection{Measurement of albumin levels}

Albumin levels were examined before and after treatment. The direct treatment group was compared with the control group. Measurement of albumin levels was carried out using a kit from DiaSys. Blood was taken as much as $10 \mu \mathrm{L}$ then put into a test tube, then mixed with reagents (ie a mixture of bromocresol green and citrate buffer) as much as $1000 \mu \mathrm{L}$. As a blank, $10 \mu \mathrm{L}$ aquades are used which are mixed with $1000 \mu \mathrm{L}$ reagents. The two solutions were then incubated for 10 mins and their absorbance was read against the reagent blank using a spectrophotometer at a wavelength of $540 \mathrm{~nm}$ (Sammad et al., 2017). Albumin levels can be calculated using the formula:

$$
\text { Albumin levels }(\mathrm{g} / \mathrm{dL})=\frac{\text { Sample scale } \times \text { Standard concentration }}{\text { Standard scale }}
$$

\subsection{Statistical analysis}

Data analysis using the SPSS application with the Windows operating system. Analysis of differences in pre-test and post-test data. Normal data, then to determine differences in growth and albumin levels of rats before and after treatment using paired t-test. If the data are not normal, the comparative test before and after each group's treatment uses the Wilcoxon test. Analysis of differences in effect between groups during treatment on albumin levels using the Kruskal Wallis testand the Mann Whitney test.

\section{Results and discussion}

Albumin levels were analyzed twice before and after the intervention. The results of measurements of albumin levels in mice before and after treatment can be seen in Table 2.

The results of normality tests for albumin levels using Shapiro Wilk in the treatment groups T1 (0.677), T3 (0.804), and T4 (0.487) data were stated to be

Table 2. Average albumin levels $(\mathrm{g} / \mathrm{dL})$ in rats before and after treatment

\begin{tabular}{cccccc}
\hline \multirow{2}{*}{ Group of Rats } & \multicolumn{2}{c}{ Mean } & \multirow{2}{*}{ p $^{\prime}$} \\
\cline { 2 - 4 } & Pre-test \pm SD & Post-test \pm SD & & $p$ & 0 \\
C & $3.46 \pm 0.41$ & $3.53 \pm 0.38$ & $0.07 \pm 0.57$ & $0.043^{*}$ & 0 \\
T1 & $3.76 \pm 0.23$ & $4.41 \pm 0.15$ & $0.64 \pm 0.089$ & $0.000^{* *}$ & \\
T2 & $3.34 \pm 0.12$ & $4.89 \pm 0.30$ & $1.55 \pm 0.39$ & $0.043^{*}$ & \\
T3 & $3.46 \pm 0.19$ & $4.57 \pm 0.92$ & $1.11 \pm 0.22$ & $0.000^{* *}$ & \\
T4 & $3.35 \pm 0.12$ & $3.94 \pm 0.76$ & $0.60 \pm 0.12$ & $0.000^{* *}$ & \\
\hline
\end{tabular}

*Wilcoxon test, ${ }^{* *}$ Paired $t$-test, $p^{\prime}=$ Kruskal Wallis test 
normally distributed $(\mathrm{p}>0.05)$. Normal test in the treatment group C (0.022) and T2 (0.015) data was stated to be abnormally distributed $(\mathrm{p}<0.05)$. Then continued the Wilcoxon test (for $\mathrm{C}$ and $\mathrm{T} 2$ ) and the Paired t-test (for T1, T3, and T4) which showed that there was a significant increase in albumin levels in all treatment groups namely group $\mathrm{C}(\mathrm{p}=0.043), \mathrm{T} 1 \quad(0.000), \mathrm{T} 2$ $(0.043), \mathrm{T} 3(0.000)$, and T4 (0.000). A mean increase in albumin levels was recorded in the $\mathrm{T} 2$ group $(1.55 \pm 0.39)$.

This study showed an increase in albumin levels carried out the Wilcoxon test and Paired t-test with a result of $p<0.05$. This proves that there is a significant increase in albumin levels in all treatment groups because each group is given a different treatment. The difference in treatment is the amount of protein source composition of complementary feeding material for skim milk, mung bean flour, and FPH flour for the treatment groups $\mathrm{T} 1, \mathrm{~T} 2$, and $\mathrm{T} 3$. In the control group, only standard AIN-93G feed and T4 treatment group were given commercial complementary feeding $\left(\right.$ Promina $\left.^{\circledR}\right)$. Increased albumin levels occur because the composition of complementary feeding has a nutrient content that is rich in protein. This study is in line with previous research, namely instant baby porridge formula with the highest profile of albumin and beta-carotene in the formula of $20 \%$ cork fish meal and $15 \%$ pumpkin flour, with albumin value of $2.20 \%$ and beta-carotene 3.40 $\mathrm{mg} / 100 \mathrm{~g}$ of vitamin A $283.33 \mu \mathrm{g} / 100 \mathrm{~g}$ (Sari et al., 2017).

Significant differences between the treatment groups after complementary feeding treatment in groups $\mathrm{T} 1$ $(\mathrm{p}=0.008), \quad \mathrm{T} 2 \quad(\mathrm{p}=0.008), \quad \mathrm{T} 3 \quad(\mathrm{p}=0.008), \quad$ and $\mathrm{T} 4$ $(p=0.008)$ when compared to group $\mathrm{C}$ can be seen in Table 3. This proves that the administration of complementary feeding can increase rat albumin levels when compared to the standard feed AIN-93G. T2 and T3 treatment groups have a significant difference when compared to the T4 group, this proves that the administration of complementary feeding (skim milk, FPH flour, and mung bean flour) can increase albumin levels when compared to commercial complementary feeding (Promina ${ }^{\circledR}$ ). Statistical test results also showed that there were no significant differences between the treatment groups $\mathrm{T} 1$ compared to $\mathrm{T} 4(\mathrm{p}=0.421)$, this proves that the complementary feeding $\mathrm{T} 1$ treatment group (18\% skim milk, 7.6\% FPH flour, and $37.8 \%$ bean flour green) and T4 (Promina ${ }^{\circledR}$ ) have the same effect if given to mice will produce albumin levels that are not much different. There was no significant difference in the T2 treatment group when compared to T3 (0.095), this proves that the administration of complementary feeding (skim milk, FPH flour, and mung bean flour) has the same effect but can increase and produce albumin levels that are not far off different. The amount of protein in food recommended by the Recommended Dietary Allowance (RDA) is $0.8 \mathrm{~g} / \mathrm{kg}$ body weight per day or about $10 \%$ of total calories per day. (Rauza et al., 2017). The main ingredients of the complementary feeding constituent protein source for the treatment groups T1, T2, and T3 were skim milk, FPH flour, and green bean flour. The amount of material composition is different, so the protein content is also different between the treatment groups $\mathrm{T} 1, \mathrm{~T} 2$, and $\mathrm{T} 3(15.6 \%, 15.825 \%$, and $16.15 \%)$. The complementary feeding $\mathrm{T} 4$ treatment group is commercial (Promina ${ }^{\circledR}$ ) with a protein content of $15 \%$. Protein content in the control treatment group was $20 \%$ of the standard feed of AIN-93G.

In this study, it was found that a higher amount of protein may not necessarily increase albumin levels. But the number of amino acids present in proteins can increase albumin levels. FPH flour as a source of protein that has the amino acid types of glutamic, aspartic acid, leucine and lysine is the most dominant constituent of protein hydrolyzate (Nurhayati et al., 2014). Green beans contain quite high amino acids and some vitamins that are needed by the body, namely the amino acid tryptophan and lysine (Yusuf, 2014). Skim milk contains essential amino acids (Susanti and Hidayat, 2016). This is in line with previous research, namely instant baby porridge that is recommended for consumption is formula D, namely the substitution of catfish $20 \%$ and pumpkin $15 \%$. Serving dose $(25 \mathrm{~g})$ instant baby porridge can fulfill $34 \%$ of protein adequacy and $102 \%$ of vitamin A adequacy. Instant baby pulp with catfish flour and pumpkin flour substitution meet the nutritional requirements, has the right density and acceptability (Noer et al., 2014). Certain amino acids such as tryptophan, arginine, lysine, phenylalanine, glutamine,

Table 3. Mann Whitney test changes in albumin Levels $(\mathrm{g} / \mathrm{dL})$ before and after treatment

\begin{tabular}{ccccccc}
\hline Group of Rats & $\Delta$ Albumin Levels $(\mathrm{g} / \mathrm{dL})$ & $\mathrm{C}$ & $\mathrm{T} 1$ & $\mathrm{~T} 2$ & $\mathrm{~T} 3$ & $\mathrm{~T} 4$ \\
\hline C & $0.07 \pm 0.57$ & - & $0.008^{*}$ & $0.008^{*}$ & $0.008^{*}$ & $0.008^{*}$ \\
$\mathrm{~T} 1$ & $0.64 \pm 0.089$ & - & - & $0.008^{*}$ & $0.008^{*}$ & 0.421 \\
$\mathrm{~T} 2$ & $1.55 \pm 0.39$ & - & - & - & 0.095 & $0.008^{*}$ \\
T3 & $1.11 \pm 0.22$ & - & - & - & - & $0.008^{*}$ \\
T4 & $0.60 \pm 0.12$ & - & - & - & - & - \\
\hline
\end{tabular}

*value $\mathrm{p}<0.05=$ significant 
alanine, threonine, and proline can stimulate albumin synthesis (Nugroho, 2012).

Normal albumin levels in mice are 3.40-4.8 g/dL. In this study all the average albumin levels in all groups were normal. In this study all the average albumin levels in all groups were normal. This study is in line with previous studies, which found no correlation between the amount of protein with levels of leptin, hemoglobin, and leukocytes but in this study, it was found that the amount of protein correlated with albumin levels after treatment for 2 weeks and 4 weeks and correlated with IgG levels after treatment for 2 weeks. (Anggraeny et al., 2016).

The measurement of albumin levels can be used to monitor the presence of malnutrition (Kuyuza, 2007). Increased albumin levels are caused by an increase in protein consumption, and conversely, a decrease in albumin levels is caused by a lack of protein consumption poor nutrition, illness, surgery, and cancer (Chowdhury et al., 2008; Alberti and Petroianu 2010; Mustafa et al,. 2012; Sari et al., 2014). This study proves that the complementary feeding formula with fish protein hydrolyzate (FPH) substitution for 14 days is very beneficial to increase albumin levels.

\section{Conclusion}

This study showed that there were significant differences in albumin levels $(\mathrm{p}>0.05)$. The complementary feeding formula with the highest albumin content at T2 $(4.89 \mathrm{~g} / \mathrm{dL})$. Formula T2 can be considered for alternative complementary feeding formula using local food.

\section{Acknowledgments}

The author thanks the National Innovation System Research Incentive (INSINAS) as a source of research funding contract no 5/INS-2/PPK/E-4/2018 Prof. Dr Ekowati Chasanah.

\section{References}

Alberti, L.R. and Petroianu, A. (2010). Importance of the evaluation of serum albumin concentration in postoperative period of patients submitted to major surgeries. Arquivos Brasileiros De Cirurgia Digestiva, 23(2), 86-89. https://doi.org/10.1590/ S0102-67202010000200005

Anggraeny, O., Dianovita, C., Putri, E.N., Sastrina, M., and Dewi, R.S. (2016). The Correlation of Low Protein Diet Administration on Status of Protein, Immunity, Hemoglobin, and Appetite of Male Wistar Rats Rattus norvegicus). Indonesian Journal of Human Nutrition, 3(2), 105-122. https:// doi.org/10.21776/ub.ijhn.2016.003.02.6 [In Bahasa Indonesia].

Asriyana and Irawati, N. (2018). Food and feeding strategy of sunrise goatfist Upeneus sulphureus, Cuvier (1829) in Kendari Bay, Southeast Sulawesi. Jurnal Iktiologi, 18(1), 23-39. https:// doi.org/10.32491/jii.v18i1.372 [In Bahasa Indonesia].

Banh, L. (2006). Serum proteins as markers of nutrition: What Are We Treating? Practical gastroenterology, 30(10), 43, 46-64.

Chalamaiah, M., Hemalatha, R., Jyothirmayi, T. (2012). Fish protein hydrolysates: proximate composition amino acid composition, antioxidant activities and applications: a review. Food Chemistry, 135(4), 3020-3038.

https://doi.org/10.1016/

j.foodchem.2012.06.100

Chowdhury, M.S.I., Akhter, N., Haque, M., Aziz, R. and Nahar, N. (2008). Serum total protein and albumin levels in different grades of protein energy malnutrition. Journal of Bangladesh Society of Physiologist, 3, 58-60. https://doi.org/10.3329/ jbsp.v3i0.1799

Gibson, R. (2005). Principle of Nutritional Assessment. $2^{\text {nd }}$ ed. New York: Oxford University Press.

Kesehatan, K., Penelitian, B. and Kesehatan, P. (2018). Hasil Utama RISKESDAS 2018. Jakarta [ID]: Balitbangkes Kementerian Kesehatan. [In Bahasa Indonesia].

Kirilova, E.M., Kalnina, I., Zvagule, T., Gabruseva, N., Kurjane, N. and Solomenikova, I.I. (2011). Fluorescent study of human blood plasma albumin alterations induced by ionizing radiation. Journal of Fluorescence, 21(3), 923-927. https:// doi.org/10.1007/s10895-010-0608-2

Kuyuza, M., Izawa, S., Enoki, H., Okada, K. and Iguchi, A. (2007). Is serum albumin a good marker for malnutrition in physically impaired elderly?. European Journal of Clinical Nutrition, 26(1), 8490. https://doi.org/10.1016/j.clnu.2006.07.009

Mardiati, S.M. and Sitasiwi, A.J. (2016). Weight Gain Mice (Mus musculus L.) after Treatment Water Seed Extract Papaya (Carica papaya Linn.) By Oral For 21 Days. Buletin Anatomi dan Fisiologi, 1(1), 75-80. https://doi.org/10.14710/baf.1.1.2016.75-80 [In Bahasa Indonesia].

Martianingsih, N., Sudrajat, H.W. and Darlian, L. (2016). Analisis Kandungan Protein Kecambah Kacang Hijau (Phaseolus radiatus L.) Terhadap Variasi Waktu Perkecambahan. Jurnal Almuni Pendidikan Biologi, 1(2), 38-42. https:// doi.org/10.33661/jai.v2i2.1180 
Muliani and Hirawati (2011). White Mouse (Mus musculus L) Growth Exposed to Barbados Nut's Seed. Anatomi Fisiologi, 19(1), 44-54. ISSN 08545367 [In Bahasa Indonesia].

Mustafa, A., Widodo, M.A. and Kristianto, Y. (2012). Albumin and zinc content of snakehead fish (Channa striata) extract and its role in health. International Journal of Science and Technology (IJSTE), 1(2), 18.

Noer, E. R., Rustanti, N. and Leiyla, E. (2014). Karakteristik makanan pendamping ASI balita yang disubstitusi dengan tepung ikan lele dan labu kuning. Jurnal Gizi Indonesia (The Indonesian Journal of Nutrition), 2(2), 82-88. [In Bahasa Indonesia].

Nugroho, M. (2012). Pengaruh suhu dan lama ekstraksi secara pengukusan terhadap rendemen dan kadar albumin ikan gabus (Ophiocephalus striatus). TEKNOLOGI PANGAN: Media Informasi dan Komunikasi Ilmiah Teknologi Pertanian, 3(1), 64-75. https://doi.org/10.35891/tp.v3i1.487 [In Bahasa Indonesia].

Nurhayati, T., Salamah, E. and Cholifah, N.R. (2014). Optimaization Process Production Hydrolysates of Protein Barramudi Viscera. Jurnal Pengolahan Hasil Perikanan Indonesia, 17(1), 42-52. https:// doi.org/10.17844/jphpi.v17i1.8136 [In Bahasa Indonesia].

Putri, Y.I., Anwar, S., Afifah, D.N., Chasanah, E., Fawzya, Y.N. and Martosuyono, P. (2019). Optimization of Formula for High Protein -Complementary Food using Fish Protein Hydrolysate and Mung Bean Flour by Response Surface Methodology. Jurnal Aplikasi Teknologi Pangan, 8(4), 123-129. https://doi.org/10.17728/ jatp. 4346

Rauza, I. and Andina, M. (2017). The Relationship of Body Mass Index in Malnourished Children to Total Protein and Albumin. Bulletin Farmatera, 2(3), 132139. https://doi.org/10.30596/bf.v2i3.1061 [In Bahasa Indonesia].

Sammad, F., Athiroh, A.S.N. and Santoso, H. (2017). Pemberian Ekstrak Metanolik Scurrula Atropurpurea (Bi) Dans Secara Subkronik Terhadap Protein Total Dan Albumin Tikus Betina. Biosaintropis, 2(2), 4954.

Setyani, S., Sari, N.R., Kuswandari, E. and Yuliana, N. (2013). The Effect of Tempeh Yeast Concentration and Fermentation of Corn on Organoleptic and Physicochemical Properties of Complementary Feeding Formula with Tempeh Flour. Jurnal Teknologi and Industri Hasil Pertanian, 18(1), 5261.
Smith, C., Allan, D., Marks, and Lieberman, M. (2007). Mark's Basic Medical Biochemistry. A Clinical Approach. $2^{\text {nd }}$ ed. California, USA: Lippincott Williams and Wilkins.

Susanti, R. and Hidayat, E. (2016). Profil Protein Susu dan Produk Olahannya. Jurnal Mipa, 39(2), 98-106. [In Bahasa Indonesia].

Sari, D.K., Rosidi, A. and Rahmawati, H. (2017). Profiles of Albumin and Beta Carotene on Formulation of Instant Baby Porridge. Jurnal Pengolahan Hasil Perikanan Indonesia, 20(3), 600606. https://doi.org/10.17844/jphpi.v20i3.19817 [In Bahasa Indonesia].

Sari, D.K., Marliyati, S.A., Kustiyah L. and Khomsan, A. (2014). Role of biscuits enriched with albumin protein from snakehead fish, zinc and iron on immune response of under five children. Pakistan Journal of Nutrition, 13(1), 28-32. https:// doi.org/10.3923/pjn.2014.28.32

Yusuf. (2014). Pemanfaatan kacang hijau sebagai pangan fungisonal mendukung diversifikasi pangan di Nusa Tenggara Timur presented at Prosiding Seminar Hasil Penelitian Tanaman Aneka Kacang dan Umbi 2014, p. 741-746. Indonesia: Pusat Penelitian dan Pengembangan Tanaman Pangan, Badan Penelitian dan dan Pengembangan Tanaman Pangan, Kementerian Pertanian. [In Bahasa Indonesia]. 